\title{
The term basal plate of the human placenta as a source of functional extravillous trophoblast cells
}

\author{
Alexandre U Borbely ${ }^{1 \dagger}$, Silvana Sandri ${ }^{2 \dagger}$, Isabella R Fernandes ${ }^{3}$, Karen M Prado ${ }^{1}$, Elaine C Cardoso ${ }^{1}$, Simone Correa-Silva ${ }^{1}$, \\ Renata Albuquerque ${ }^{2}$, Martin Knöfler ${ }^{4}$, Patricia Beltrão-Braga ${ }^{3,5}$, Ana Campa ${ }^{2}$ and Estela Bevilacqua ${ }^{*}$
}

\begin{abstract}
Background: Extravillous trophoblast (EVT) cells are of pivotal importance in human embryo implantation and homeostasis of the maternal fetal interface. Invasion of the endometrium by EVT contributes to placental anchorage, spiral artery remodeling, immunological defense, tolerogenic responses, and several collaborative cross talks involved in establishing and maintaining a successful pregnancy. We report here an improved protocol for the isolation of fully differentiated EVT cells from the basal plate of the human term placenta.
\end{abstract}

Methods: The basal plate was carefully dissected from the villous tissue and the amniochorion membrane prior to enzymatic digestion. Term basal EVT cells were isolated using a 30 and 60\% Percoll gradient. A panel of markers and characteristics of the isolated cells were used to confirm the specificity and efficiency of the method so that their potential as an investigative tool for placental research could be ascertained.

Results: Isolated cells were immunoreactive for cytokeratin-7 (CK-7), placental growth factor, placental alkaline phosphatase, human leukocyte antigen G1 (HLA-G1), and a1 and a5 integrins, similarly to the EVT markers from first trimester placental villi. Around 95\% of the isolated cells labeled positively for CK-7 and 82\% for HLA-G1. No significant change in viability was observed during $48 \mathrm{~h}$ of EVT culture as indicated by propidium iodide incorporation and trypan blue test exclusion. Genes for metalloproteinases MMP-2 and MMP9 (positive regulators of trophoblast invasiveness) were expressed up to $48 \mathrm{~h}$ of culturing, as also the gelatinolytic activity of the isolated cells. Transforming growth factor (TGF)-beta, which inhibits proliferation, migration, and invasiveness of first-trimester EVT cells, also reduced invasion of isolated term EVT cells in transwell assays, whereas epidermal growth factor was a positive modulator.

Conclusions: Term basal plate may be a viable source of functional EVT cells that is an alternative to villous explant-derived EVT cells and cell lines. Isolated term EVT cells may be particularly useful in investigation of the role of trophoblast cells in pathological gestations, in which the precise regulation and interactive ability of extravillous trophoblast has been impaired.

Keywords: Basal plate, Cell isolation, Extravillous trophoblast cells, Invasiveness, Term placenta

\section{Background}

The placenta is a highly specialized essential organ that includes the chorionic villous tree and decidua. The villi are formed by the syncytiotrophoblast (ST) layer in contact with maternal blood, and the cytotrophoblast (VCT) layer, the source of proliferative cells that gives rise to the ST and the extravillous cytotrophoblast (EVT)

\footnotetext{
* Correspondence: bevilacq@usp.br

'Equal contributors

'Department of Cell and Developmental Biology, Institute of Biomedical

Sciences, University of Sao Paulo, Sao Paulo 05508-000, Brazil

Full list of author information is available at the end of the article
}

from the tips of the villi [1]. EVT differentiate in cell subpopulations, characteristically invasive, forming the trophoblastic shell and, interstitial and endovascular cells, respectively invading the decidua and myometrium and uterine vessels [2]. Invasive behavior of these cells is particularly prominent at the first-trimester, although transient, accurately regulated and spatially confined to the endometrium and part of the myometrium [2].

The biological events involved in trophoblast invasion have been compared to those of neoplastic cells [3], making the mechanisms of the former's invasiveness of

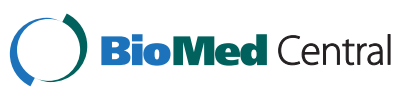


great common interest. A high incidence of invasiveness-related changes in trophoblast in adverse pregnancy outcomes, such as placenta accreta, pre-eclampsia [4] and other gestational diseases also highlights the importance of studying EVT cells [5].

First and second trimester human EVT cells constitute a prominent cell population with highly migratory/invasive activities [2]. At term, the cells are partially replaced by fibrinoid and therefore become less numerous. This cell population derives from the small spindle-shaped diploid cells found in the initial gestational trimester [6,7], having a non-proliferative profile, tendency towards polygonal column formation with polyploidy, and reduced invasive activity [8]. These characteristics have been considered disadvantageous for using term basal plate EVT cells. Use of first and second trimester pregnancy tissues, however, depends on ethical considerations and legal regulations, which differ among countries. Hence, term placentas offer an alternative and more readily available source for EVT preparations. Cultured EVT cells also share common phenotypic characteristics in spite of the different protocols described for the isolation first, second and third trimester cells [9-19]. EVT also play key roles in maternal immunoregulation and the molecular regulatory dialogue at the maternal fetal interface. Absence or unregulated production of regulatory factors has been reported in placental-associated gestational pathologies $[4,5,8]$. In this context, the study of cytotrophoblast cells directly from these microenvironments would allow the analysis of a multitude of impaired signaling pathways, bringing new ways of interpreting the causes and consequences of these pathological conditions.

Villous tissue, villous explant outgrowth, and amniochorion membrane are useful sources from which trophoblast cells can be isolated [9-19]. Explant cultures of anchoring villi and VCT/EVT cells isolated from villous tissue obtained from first-trimester placentas have also been used successfully to yield migratory, temporarily proliferative cytotrophoblast cells for differentiation and invasion studies $[9,12]$. The contribution of these procedures to elucidating the physiology and paracrine regulation of trophoblast cells is inestimable [20-23]. Third trimester explants and villous digestion have also been used to yield VCT cells [15,16], although they produced fewer viable and invasive VCT/EVT cells than first trimester explants. Terminally differentiation of third trimester VCT cells in vivo is considered an experimental obstacle $[11,24]$.

Term EVT cells can also be isolated in large quantities from the amniochorion membrane [15,17]. These cells tend to merge in vitro, resulting in giant polyploid multinucleated trophoblast cells [17], which are phenotypically and functionally different from in vivo EVT cells in respect of invasive and interactive behavior. The transformation of mononuclear EVT cells into giant multinucleated trophoblast cells and polyploidization seem to be mechanisms associated with villous trophoblast differentiation [24], but not with the multiple particular features of the in vivo extravillous cytotrophoblast inhabiting the decidua. EVTs from decidual basal plate are also in direct contact to maternal cells, which may be important in getting a better understanding of the invasive and tolerance process promoted by these cells.

Thus, we investigated whether the basal plate from term placenta might be a viable source of fully differentiated EVT cells that can be used as a model of trophoblast biology in healthy and pathological conditions.

\section{Methods}

Reagents

Collagenase type II, insulin, calcium lactate, sodium pyruvate, nucleosides, Trypan blue and fish skin gelatin (Sigma Chemical Co., St. Louis, USA). Antibiotics, 4',6' -diamino2-phenylindole dihydrochloride (DAPI), deoxynuclease (DNAse) type I, Dulbecco's Modified Eagle Medium: Nutrient Mixture F-12 (DMEM/F12), fetal bovine serum (FBS), fibronectin, Iscove's Modified Dulbecco's Medium (IMDM), Tryzol ${ }^{\circ}$ reagent, SuperScript ${ }^{\circ}$ First Strand kit, and Taq Polymerase (Invitrogen Carlsbad, USA). Matrigel, transwell inserts and filters (Becton Dickinson, Franklin Lakes, USA). Other reagents were from Merck, Darmstadt, Germany) unless otherwise indicated. The specificities and sources of antibodies are listed in Table 1.

\section{Tissue collection}

Twenty term placentas (37-40 weeks) were obtained from women having elective Caesarean section with healthy babies with no pregnancy complications. Ethical committee approval for this study was granted by the University Hospital and the Institute of Biomedical Sciences from University of Sao Paulo, and informed consent was obtained before surgery. Pools of first trimester placentas (6-12 weeks) were obtained from legal abortions of uncomplicated pregnancies. The use of these tissues was approved by the ethical committee of the Medical University of Vienna.

\section{Isolation of EVT cells}

The term basal plate is a 3-6 mm thick membrane (Figure 1A-B), which was carefully dissected from the villous tissue and the amniochorion membrane. Isolation of EVT cells was adapted from a previously described procedure for amniochorion cytotrophoblast isolation $[15,25]$. Briefly, the fragments were coarsely minced and $\sim 5 \mathrm{~g}$ of wet tissue were incubated for $1 \mathrm{~h}$ with $20 \mathrm{~mL}$ of DMEM/F12 containing 4\% bovine serum albumin (BSA), collagenase type II $(125 \mathrm{U} / \mathrm{mL})$ and DNase type I $(25 \mathrm{U} / \mathrm{mL})$, at $37^{\circ} \mathrm{C}$ in a water bath, followed by 
Table 1 List of antibodies

\begin{tabular}{|c|c|c|c|}
\hline Antibody & Isotype & Dilution & Source \\
\hline Mouse monoclonal anti-human CK-7 & $\lg G 1$ & $1: 100$ & Dako Norden A/S (Glostrup, Denmark) \\
\hline Mouse monoclonal anti-human HLA-G1 & $\lg G 1$ & $1: 100$ & Exbio (Prague, Czech Republic) \\
\hline Mouse monoclonal anti-human Vm & $\lg G 2 a$ & 1:50 & Dako Norden A/S (Glostrup, Denmark) \\
\hline Rabbit polyclonal anti-hunan PIAP & $\lg G 1$ & Ready to use & Invitrogen (Carlsbad, CA, USA) \\
\hline Rabbit polyclonal anti-human PIGF & $\lg G 1$ & $1: 100$ & Abcam (Cambridge, UK) \\
\hline Rabbit polyclonal anti-human a1 integrin & $\lg G 1$ & $1: 100$ & Millipore (Billerica, MA, USA) \\
\hline Mouse monoclonal anti-human a5 integrin & $\lg G 1$ & 1:50 & Abcam (Cambridge, UK) \\
\hline Mouse monoclonal anti-human desmoplakin I/II & $\lg G 1$ & $1: 200$ & Abcam (Cambridge, UK) \\
\hline Mouse monoclonal anti-human CD68 & $\operatorname{lgG1}$ & $1: 50$ & Dako Norden A/S (Glostrup, Denmark) \\
\hline Rabbit polyclonal anti-human a6 integrin & $\lg G 1$ & $1: 100$ & Abcam (Cambridge, UK) \\
\hline FITC labeled rabbit anti-mouse $\lg G$ & $\lg G 1$ & $1: 20$ & Dako Norden A/S (Glostrup, Denmark) \\
\hline TRITC labeled goat anti-rabbit lgG & $\operatorname{lgG} 1$ & $1: 50$ & Sigma Chemical Co (St. Louis, MO, USA) \\
\hline AlexaFluor 488 labeled rabbit anti-mouse lgG & $\operatorname{lgG1}$ & $1: 1000$ & Molecular Probes (Eugene, OR, USA) \\
\hline AlexaFluor 568 labeled goat anti-rabbit lgG & $\operatorname{lgG1}$ & $1: 1000$ & Molecular Probes (Eugene, OR, USA) \\
\hline Zenon ${ }^{\circledast}$ Alexa Fluor 488 anti-mouse & $\lg G_{1}$ & See supplier's instruction & Invitrogen (Carlsbad, CA, USA) \\
\hline Zenon ${ }^{\circledast}$ R-phycoerythrin anti-mouse & $\lg G_{1}$ & See supplier's instruction & Invitrogen (Carlsbad, CA, USA) \\
\hline
\end{tabular}

inactivation with 20\% FBS. Cell suspension was doublefiltered through a $100 \mu \mathrm{m}$ mesh followed by a $70 \mu \mathrm{m}$ mesh. The suspension was centrifuged at $400 \times \mathrm{g}$ and the cells washed and resuspended in complete DMEM/F12 (supplemented with 1\% antibiotics, 10\% FBS, 0.01\% insulin, $520 \mu \mathrm{g} / \mathrm{mL}$ calcium lactate, $56 \mu \mathrm{g} / \mathrm{mL}$ sodium pyruvate and $1 \%$ nucleosides). EVT cells were isolated using a gradient of 30 and 60\% Percoll (GE Healthcare, Uppsala,
Sweden) followed by centrifugation at $700 \times \mathrm{g}$ for $30 \mathrm{~min}$ [25]. EVT cells were collected from the top of the $30 \%$ gradient. When needed, the cell suspension was incubated with $0.83 \%$ ammonium chloride in PBS and centrifuged at $400 \times \mathrm{g}$ for $5 \mathrm{~min}$ for blood cell removal.

For some comparative analyses, first trimester EVT were also isolated from pooled villous tissue. The procedure followed steps previously described [26], using

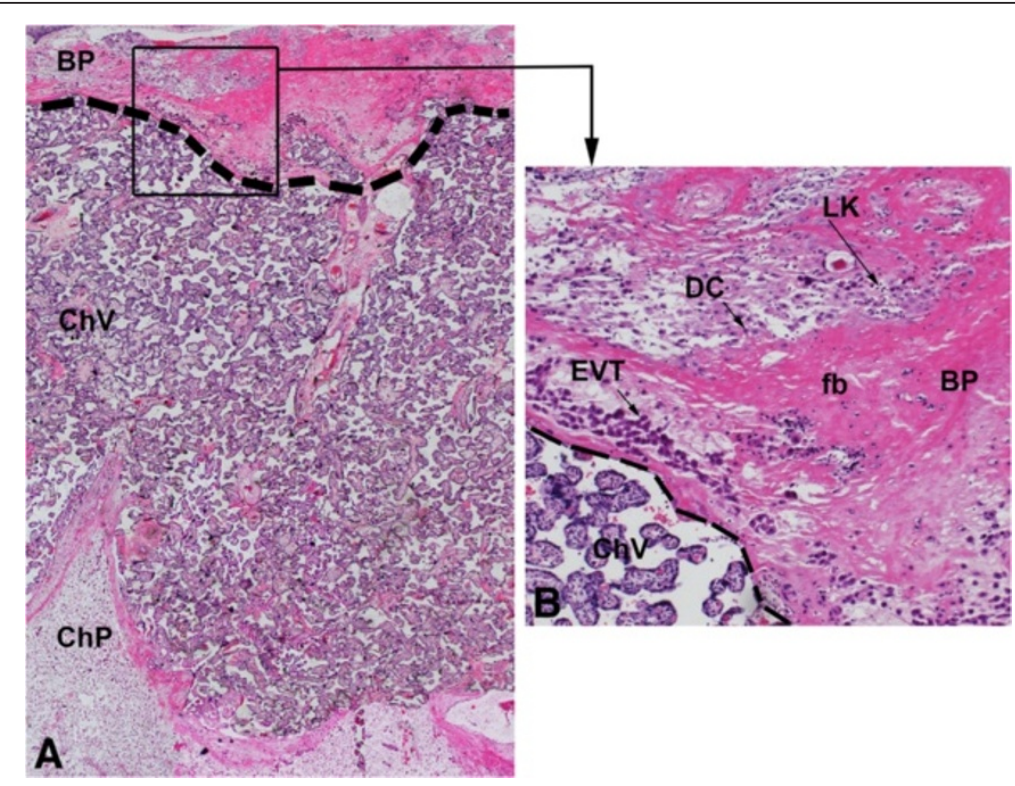

Figure 1 The term decidual basal plate. (A) Panoramic view (25x) showing the basal plate (BP), chorionic villi (ChV) and the chorionic plate (ChP) of the human placenta. Dotted line indicates the area initially dissected for isolation of EVT cells. (B) High magnification (100x) of the square highlighted in Figure A, in which are indicated extravillous cytotrophoblast cells (EVT), decidual cells (DC) and leukocytes (LK) at the basal plate (BP). (fb) fibrinoid. (ChV) chorionic villi. Hematoxylin-eosin staining. 
adapted enzymatic dispersion and Percoll density gradient centrifugation (GE Healthcare).

\section{Cell culture}

The isolated cells were plated on culture dish plates (Corning Incorporated, Corning, NY, USA) coated with Matrigel (1:1 in DMEM/F12) or fibronectin $(10 \mu \mathrm{g} / \mathrm{mL}$ in PBS). Plated cells were incubated for $12 \mathrm{~h}$ at $37^{\circ} \mathrm{C}$ under a humidified atmosphere of $5 \% \mathrm{CO}_{2}$ in air for cell attachment. Non-adherent cells were washed out, and complete DMEM/F12 or IMDM supplemented with $10 \%$ FBS was added.

\section{Immunofluorescence}

Isolated cells $\left(3 \times 10^{5}\right.$ cells/well) plated out for $48 \mathrm{~h}$ were fixed in ice-cold methanol. For blocking, 0.05\% fish skin gelatin in PBS was used and cells were incubated with primary antibody followed by incubation with fluorescent secondary antibody or incubated with Zenon ${ }^{\circ}$ Tricolor mouse IgG labeling kit (Table 1). Nuclei were stained with $0.2 \mu \mathrm{M}$ DAPI. The coverslips were mounted with 1:9 (v/v) PBS/glycerol. Fluorescent cells were quantified as the percentage of reactive cells in the total number of stained nuclei per microscopic field, in a total of 4 fields per sample, with at least 3 samples used on different occasions. Negative controls were developed by adding un-related antibodies.

\section{Flow cytometry}

For cell viability assays, cells $\left(3 \times 10^{5}\right.$ cells/well $)$ were labeled with $2 \mu \mathrm{g} / \mathrm{mL}$ propidium iodide (PI) and analyzed by FACS Canto ${ }^{\circ}$ flow cytometry (Becton Dickinson). For intracellular labeling, cells $\left(3 \times 10^{5}\right.$ cells/well $)$ were incubated in 5\% normal goat serum (Vector Laboratories, Burlingame, USA), washed, fixed and permeabilized using commercial buffers (e-Bioscience, San Diego, USA). The cells were incubated in permeabilization buffer with target antibody previously conjugated with a Zenon ${ }^{\circledR}$ Tricolor mouse IgG labeling kit. They were finally resuspended in $0.1 \%$ BSA in PBS and analyzed, the data being handled by FlowJo ${ }^{\oplus}$ software (Tree Star Inc., Ashland, USA).

\section{Trypan blue dye exclusion test}

Isolated cells $\left(2.5 \times 10^{4}\right.$ cells/well $)$ were mixed with $0.4 \%$ trypan blue dye in the ratio $1: 1(\mathrm{v} / \mathrm{v})$, and the numbers of viable and dead cells were counted using a hemocytometer.

\section{RNA extraction and RT-PCR}

Total RNA was extracted $\left(3 \times 10^{5}\right.$ cells/well $)$ using Tryzol. The RNA was assessed by ultraviolet spectrophotometry using a ND-100 spectrophotometer (Nano Drop Technologies, Rockland, USA), and the cDNA was synthesized from $1 \mu \mathrm{g}$ of total RNA using a SuperScript ${ }^{\ominus}$ First Strand kit. RT-PCR involved Taq polymerase. The primer sequences, annealing temperatures, and PCR product sizes are shown in Table 2. Thermal cycling conditions were $98^{\circ} \mathrm{C}$ for $2 \mathrm{~min}, 94^{\circ} \mathrm{C}$ for $45 \mathrm{sec}, 56^{\circ} \mathrm{C}, 60^{\circ} \mathrm{C}, 60^{\circ} \mathrm{C}$ or 54 for $45 \mathrm{sec}$, and $72^{\circ} \mathrm{C}$ for $40 \mathrm{sec}$, followed by a final extension at $72^{\circ} \mathrm{C}$ for $5 \mathrm{~min}$. PCR products were visualized with ethidium bromide after electrophoresis on 1\% agarose gel. The band densitometric analyses were performed with Image J software (National Institute of Health, Bethesda, Maryland, USA).

\section{Invasion assay}

Invasion was assayed in transwell inserts using 24-well fitted inserts with $8 \mu \mathrm{m}$ pore size. The inserts were precoated with $15 \mu \mathrm{L}$ Matrigel $(1: 1 \mathrm{v} / \mathrm{v}$ in DMEM/F12) or $30 \mu \mathrm{L}$ fibronectin $\left(10 \mu \mathrm{g} / \mathrm{mL}\right.$ in PBS). Cells $\left(5.6 \times 10^{4}\right.$ cells/well $)$ were resuspended in complete DMEM/F12, treated with $10 \mathrm{ng} / \mathrm{mL}$ TGF- $\beta$ or $50 \mathrm{ng} / \mathrm{mL}$ EGF, and seeded. The lower chambers were loaded with complete DMEM/F12. Noninvading cells were removed after $48 \mathrm{~h}$, and the membranes fixed and stained with $0.2 \%$ violet crystal dye.

\section{DNA incorporation by BrDUr}

Cells plated at $3 \times 10^{5}$ cells/well and cultured for 24 and $48 \mathrm{~h}$ were used to assess proliferation rates. Cultured cells were incubated with $1.5 \mu \mathrm{g} / \mathrm{mL}$ 5-bromo-2'-deoxyuridine (Merck, Darmstadt, Germany) in DMEM/F12 complete medium for $3 \mathrm{~h}$ before fixation in $4 \%$ paraformaldehyde in PBS for $20 \mathrm{~min}$ at room temperature.

Table 2 Sequence of primers used in this study

\begin{tabular}{|c|c|c|c|c|}
\hline Gene & Sequence & Number of cycles & Annealing $\left({ }^{\circ} \mathrm{C}\right)$ & Size \\
\hline \multirow[t]{2}{*}{185} & Forward: 5' GTAACCCGTTGAACCCCATT3' & 20 & 56 & $115 \mathrm{bp}$ \\
\hline & Reverse: 5' CCATCCAATCGGTAGCG 3' & & & \\
\hline \multirow[t]{2}{*}{ GADPH } & Forward: 5'CTGTTGCTGTAGCCAAATTCGT3' & 28 & 60 & $102 \mathrm{bp}$ \\
\hline & Reverser: 5'ACCCACTCCTCCACCTTTGA3' & & & \\
\hline \multirow[t]{2}{*}{ MMP-2 } & Forward: 5 AGCTCCCGGAAAAGATTGATG3' & 35 & 60 & $101 \mathrm{bp}$ \\
\hline & Reverse: 5' CAGGGTGCTGGCTGAGTAGAT3' & & & \\
\hline \multirow[t]{2}{*}{ MMP-9 } & Forward: 5' GAGGTGGACCGGATGTTCC 3' & 35 & 54 & $106 \mathrm{bp}$ \\
\hline & Reverse: 5' AACTCACGCGCCAGTAGAAG 3' & & & \\
\hline
\end{tabular}


BrDU was used to detect cells incorporating DNA, using a mouse IgG antibody against BrDU.

\section{Gelatin zymography}

The presence of proteases in the culture supernatants was detected by gelatin zymography. The harvested media were standardized according to the protein content of the cell lysates. Thirty $\mu \mathrm{g}$ total proteins were separated on 10\% SDS-PAGE gels containing $5 \mathrm{mg} / \mathrm{mL}$ gelatin. The gels were washed in $2.5 \%$ Triton $\mathrm{X}-100$ at $37^{\circ} \mathrm{C}$ and incubated overnight at $37^{\circ} \mathrm{C}$ in reaction buffer $(0.05 \mathrm{M}$ Tris- $\mathrm{HCl}$, $\left.\mathrm{pH}=8.5,10 \mathrm{mM} \mathrm{CaCl} 2,1 \mu \mathrm{M} \mathrm{ZnCl}_{2}\right)$. The gels were stained with Coomassie solution (0.5\% Coomassie brilliant blue R-250 in 10\% methanol and 10\% acetic acid) and destained in $10 \%$ methanol and $10 \%$ acetic acid. Clear zones of gelatin lysis against the blue background stain indicated the presence of gelatinolytic activity. The lysis zones from each sample lane were analyzed using Image J software (National Institute of Health, Bethesda, Maryland, USA).

\section{Photographic documentation}

An Axiovert S100 inverted light microscope (Zeiss, Jena, Germany) was used for general cell morphology and cell counting. Immunofluorescence was analyzed using an Axioskop 2 fluorescence microscope (Zeiss) and the images were taken with the program AxioVision 4.7 (Zeiss).

\section{Statistical analysis}

Statistical analyses were based on one-way analysis of variance followed by a Student-Newman-Keuls multiple comparisons test using Prism v5.0 software from GraphPad (San Diego, CA, USA).

\section{Results}

\section{Characterization and purity of term basal plate EVT}

The yield of isolated cells from the basal plate of term placenta was generally around $2-6 \times 10^{6}$ cells $/ 20 \mathrm{~g}$ tissue. After isolation, cells were homogenous, small and roundish in morphology with large nuclei and prominent nucleoli (Figure 2A). The isolated cells were not multinucleated or giant cells. Subsequently, the cells organized into columns (Figure 2B-C) and most showed enlarged polygonal cytoplasm and cell protrusions (Figure 2D-E), suggesting a migratory phenotype.

The isolated cells have not stained for vimentin $(\mathrm{Vm})$, but reacted positively to cytokeratin (CK)-7 (Figure 3B-C). Cultures of endometrial stromal cells positive to antivimentin were used as positive control (Figure 3B insert). Most were also positive for placental growth factor (PlGF) and placental alkaline phosphatase (PIAP) (Figure 3E-F). Moreover, the great majority of these cells were negative for CD68 (Figure 3G), $\alpha 6$ integrin (Figure 3H) and desmoplakin I/II (Figure 3I). By flow cytometry, an average of $95 \%$ of these cells were CK-
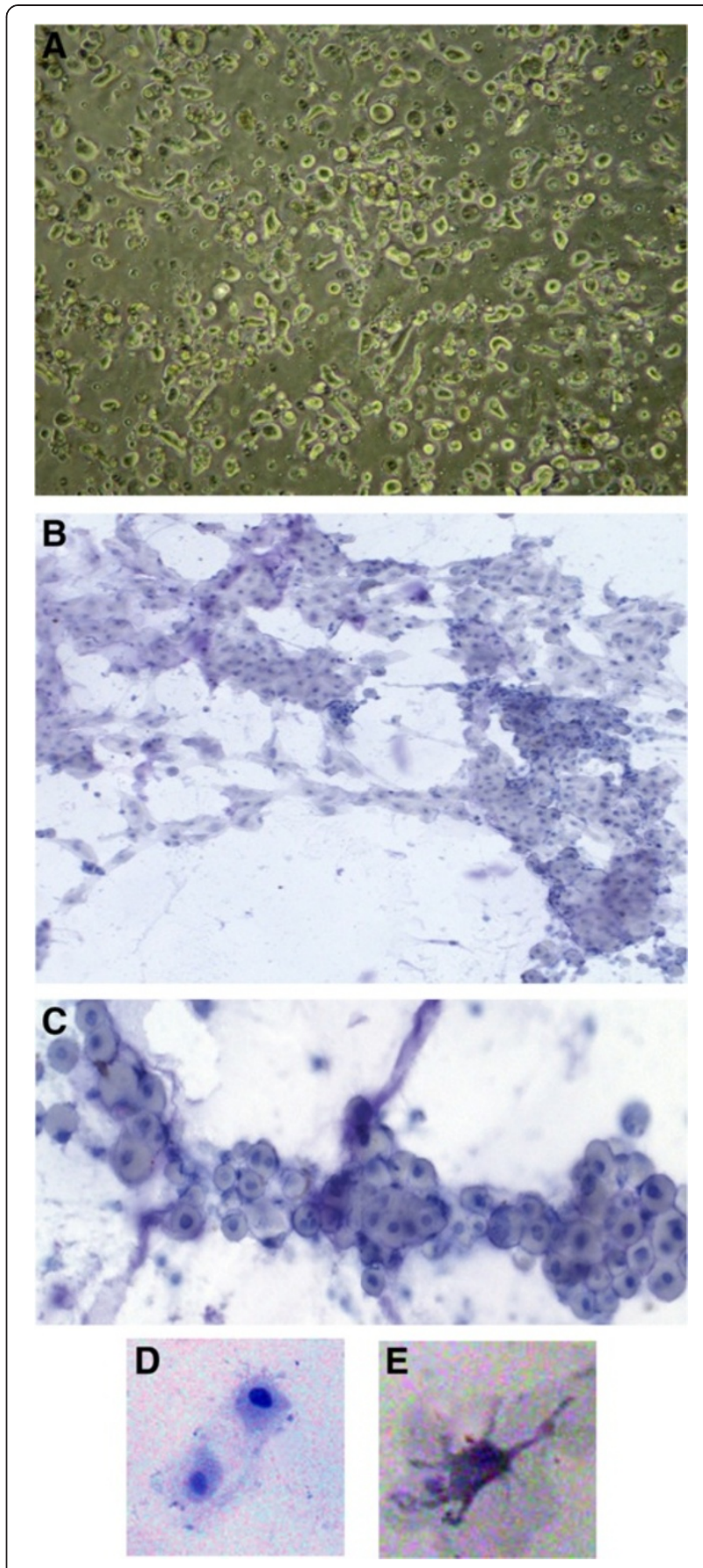

Figure 2 General morphology of isolated and cultured term basal plate cells. (A) After isolation (200x). (B) Cells organized in cell columns after $24 \mathrm{~h}$ of culture on Matrigel (200x). (C) Higher magnification of B (400x). (D-F) After $48 \mathrm{~h}$ of culture, cells exhibit projections indicating migratory activity (1000x). (A) Phase-contrast. (B-F) Mayer's hematoxylin staining.

7 positive, negative for $\mathrm{Vm}$ and $82 \%$ positive for human leukocyte antigen G1(HLA-G1), corroborating the immunofluorescence findings (Figure 4A-D). 

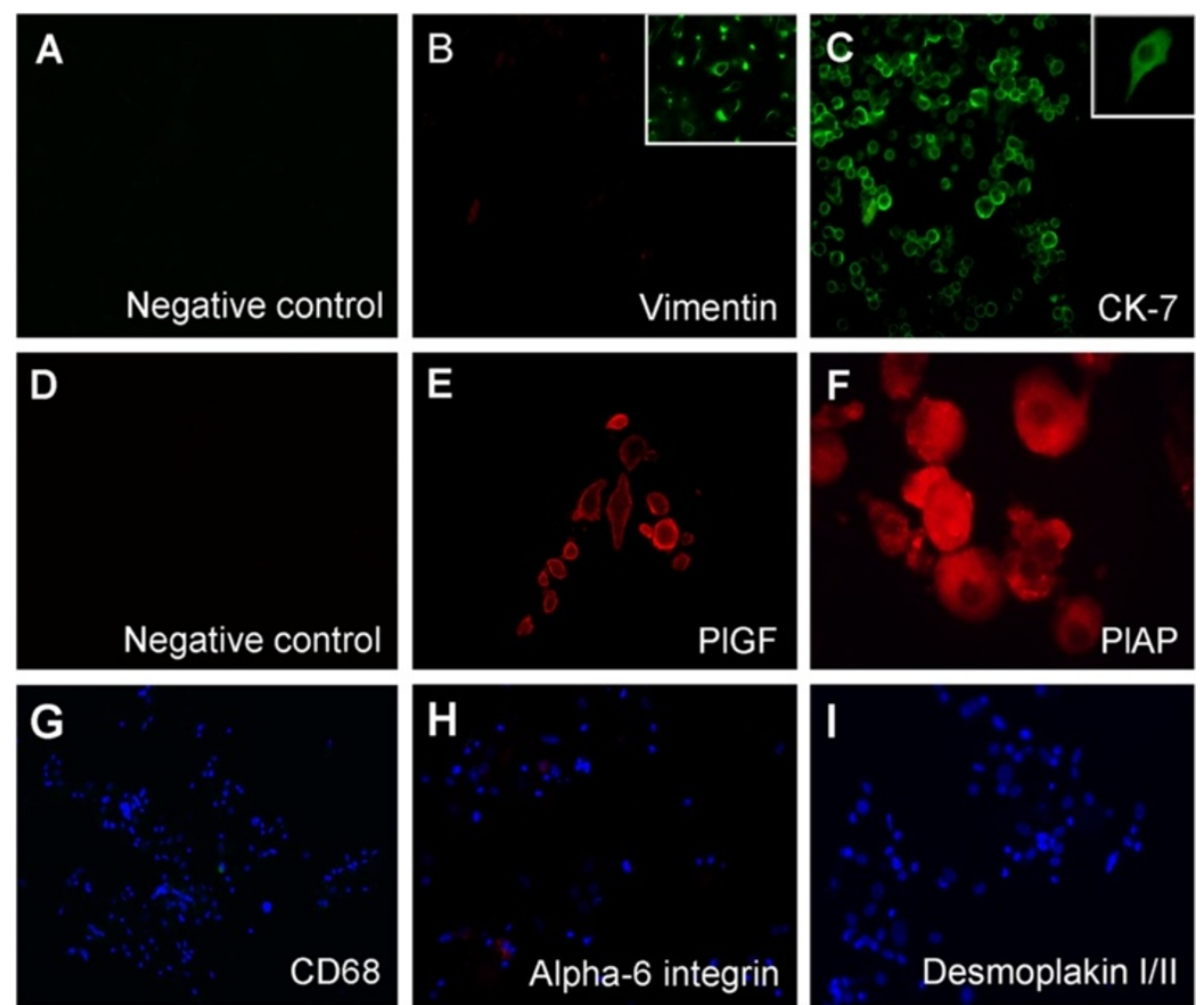

Figure 3 Representative immunofluorescence characterization and purity of isolated term basal plate cells cultured for $48 \mathrm{~h}$. (A, D) Negative controls of immunostaining. (B) Vimentin staining (200x); insert shows vimentin-expressing endometrial stromal cells (200x). (C) CK-7 staining (200x); insert shows a CK-7 positive cell exhibiting projections (1000x). (E) PIGF staining (400x). (F) PIAP staining (200x). (G) CD68 staining (200x). (H) Alpha6-integrin staining (200x). (I) Desmoplakin I/II staining (200x).

First trimester EVT cells contain a specific repertoire of adhesion molecules, closely related to the invasive process, and special antigens from the histocompatibility complex. The persistence of these characteristics in $48 \mathrm{~h}$ cultured term EVT population was also assessed and compared by immunofluorescence for HLA-G1 HLA-G1 (Figure 5B-C), 1 integrin (Figure 5E-F) and 5 integrin (Figure $5 \mathrm{H}-\mathrm{I}$ ). The percentages of HLA-G1 were quite similar between both groups, although first trimester EVT presented higher percentages of both 1 and 5 integrin expression (summarized in Table 3).

\section{Cultured term basal plate EVTs are viable and preserve mRNA expression}

Cell viability was assessed by PI incorporation and the trypan blue exclusion method at 24 and $48 \mathrm{~h}$ of culturing using different culture media with varying composition. Compared to DMEM/F12, IMDM medium has additional amino acids, vitamins and inorganic salts, besides HEPES and selenium, which could be an advantage to improve cell proliferation and viability. The two different types of medium used during cell culturing, however, have no effects on cell viability (Figure 6A-B) and proliferation. Proliferation assessed by BrDU showed that EVT cells were indeed not proliferating, as expected for terminal differentiated EVT cells (data not shown). Gene expression in term EVT cell was preserved during the culture time, as indicated by GADPH and $18 \mathrm{~S}$ gene expression (Figure 6C).

\section{Metalloproteinase expression and gelatinolytic activity}

MMP-2 and MMP-9 mRNA expression was investigated as key molecules to cell invasion. MMP-2 mRNA was expressed at all times of culture (Figure 6C-D). In contrast, expression of MMP-9 mRNA was low expressed after isolation, but it increased at $24 \mathrm{~h}$ and thereafter (Figure 6C-D). Proteolytic activity of cultured cells was also measured in the culture supernatants using gelatin zymography; gelatinolytic activity was seen when EVT cells were cultured on Matrigel (Figure $7 \mathrm{C}$ ). This activity increased in the presence of EGF and decreased in the presence of TGF- $\beta$ relative to the control (Figure 7D). The effects of EGF and TGF- $\beta$ were not so evident in the presence of fibronectin.

\section{Term basal plate EVT maintains their invasive properties} The invasion potential of EVT cells was evaluated by transwell inserts coated with Matrigel and fibronectin in 
A

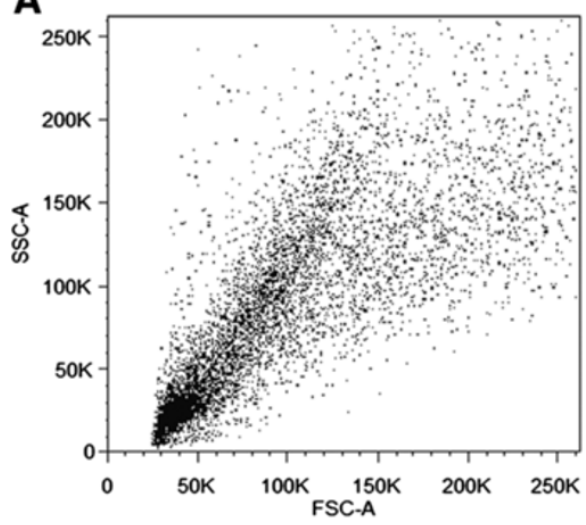

C

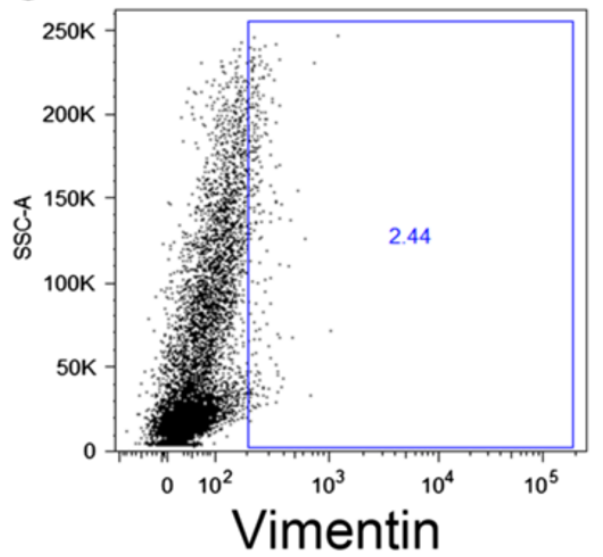

B

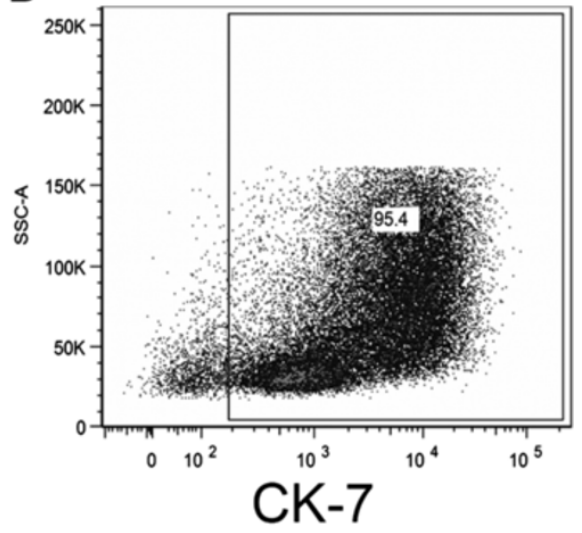

D

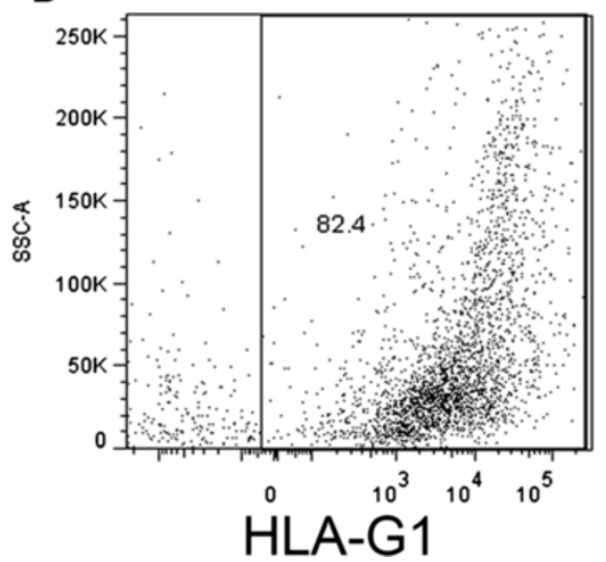

Figure $\mathbf{4}$ Representative flow cytometry characterization and purity of isolated term basal plate cells cultured for $\mathbf{4 8} \mathbf{~ h}$. Flow cytometry plots show cell size and cytoplasmic granularity (A), the amount of CK-7 positive cells (B), the amount of vimentin positive cells (C) and HLA-G1 positive cells (D). The data are representative of three independent assays.

the presence of TGF- $\beta$ and EGF at concentration of 10 and $50 \mathrm{ng} / \mathrm{mL}$, respectively. TGF- $\beta$ decreased invasion, whereas EGF led to a significant enhancement of invasive activity (Figure 7A-B). No changes in proliferation rates were seen after TGF- $\beta$ and EGF addition to the culture system (data not shown).

\section{Discussion}

We have shown that term basal plate can be a source of viable and functional EVT cells. Isolated EVT cells were positive for CK-7, PlAP, PIGF, HLA-G, and $\alpha 1$ and $\alpha 5$ integrins, the latest three markers also found in first trimester EVT. The viability of these cells and gene transcription along the culture times indicate the suitability of the methods for EVT maintenance. In addition, term EVT cells also respond differentially to regulatory molecules that inhibit or stimulate cell invasion, expressing MMP-2 and MMP-9 as well as showing gelatinolytic activity.

In this study we established a standardized procedure that was successfully applied to the isolation of EVT cells from term placentas. This protocol adapted the enzymatic cell dissociation, by using an enzymatic cocktail instead of trypsin digestion. This procedure resulted in high number of isolated and viable cells, from which EVT cells were subsequently selected by Percoll.

In contrast to villous and amniochorion membrane EVT-derived cells [15,25], EVT cells are exposed to the surrounding microenvironment of extracellular matrix components, which in turn play vital roles in the functions of these cells [26-28]. An important factor for cell viability may therefore be linked to the availability and/ or activity of certain proteins of the ECM, whose activity is mediated by cadherins, integrin-matrix ligand among others. The ability of the collagenase in dissociating EVT cells by only cleaving the peptide bonds in the triple helical collagen molecules [29,30], and therefore preserving surface cell molecules and receptors may be a differential crucial factor in our protocol.

Culturing EVT cells in different culture media could provide a myriad of beneficial results. Therefore, the effect of two culture media on the cell viability of these 


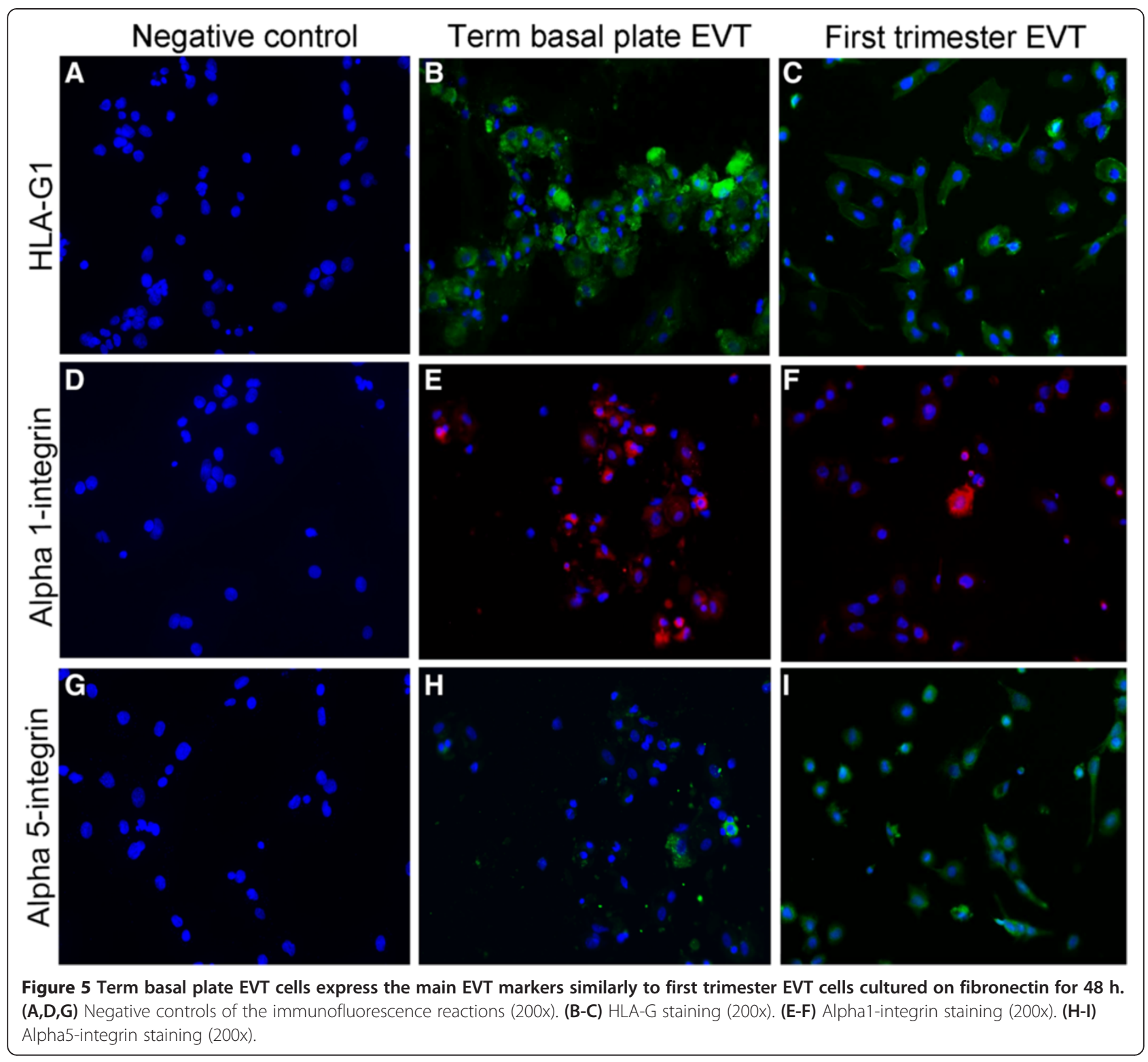

cells was also tested. DMEM/F12 provided acceptable cell viability rates when appropriately supplemented and similar to IMDM, when added of only insulin, SBF and antibiotics. Thus, culturing cells with any of these media makes the cells grow healthy, maintains their cell characteristics and keeps them differentiated and viable, although none induced proliferation.
EVT cells are the only cell type expressing cytokeratin filaments in the term basal plate, when glands and uterine epithelium are no longer present [31,32]. Thus, the expression of CK-7 and the rare or absence of vimentin and CD68 reactive cells respectively identifying mesenchyme and macrophage cell lineages, as observed herein, confirm the trophoblastic nature of

Table 3 Quantitative analysis of 48 h cultured EVT-markers

\begin{tabular}{lllll}
\hline & CK-7 (\%) & HLA-G (\%) & a1- integrin (\%) & a5- integrin (\%) \\
\hline Term Basal plate EVT & $95 \pm 3$ & $72 \pm 7$ & $52 \pm 9$ & $53 \pm 16$ \\
First trimester villous EVT & $94 \pm 5$ & $71 \pm 9$ & $64 \pm 3$ & $78 \pm 7$ \\
\hline A
\end{tabular}

A total amount of 200 DAP-I positive cells were counted from four randomly microscopic fields on $200 x$ magnification/slide ( $n=3$ slides). At the same microscopic fields using appropriated filters, double-positivity cells for CK-7 and, HLA-G1, alpha1-integrin or alpha5 integrin was also counted. The values were expressed as a percentage of the total DAP-I positive cells (According to Pollheimer et al., [26]). 

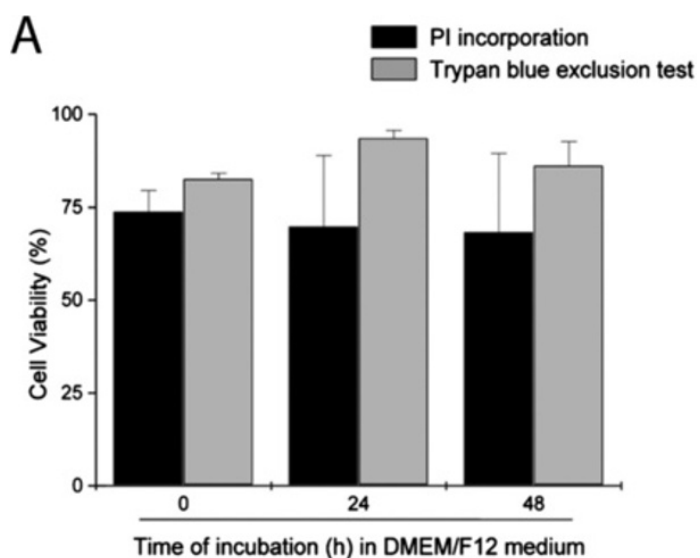

B

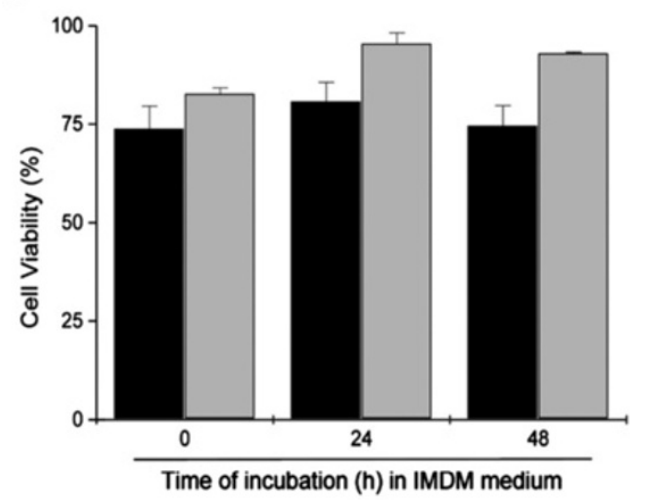

C

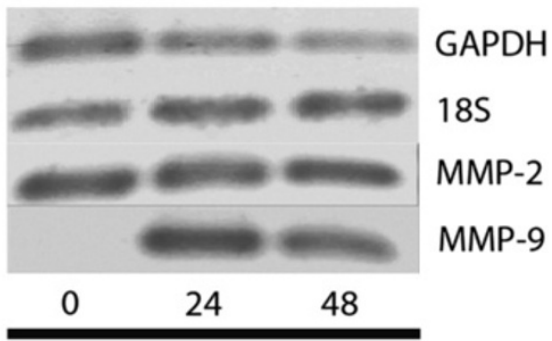

Time of Culture (h)

D

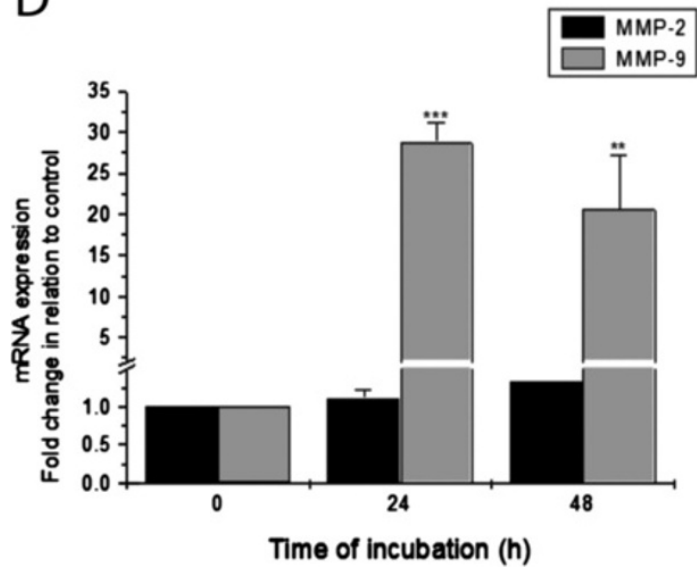

Figure 6 Cell viability and mRNA expression of term basal plate EVT cells at different times of culture. Cell viability was analyzed by $\mathrm{PI}$ incorporation and trypan blue exclusion using complete DMEM/F12 (A) and supplemented IMDM (B). The data represent the mean \pm SEM of four independent assays. (C) Agarose gel electrophoresis of amplified PCR products of GAPDH, 18S, MMP-2 and MMP-9 genes. (D) Representation of the RT-PCR data as determined by densitometric analysis of gel bands expressed as a ratio of GAPDH expression. The data represent the means \pm SEM from three independent experiments. ${ }^{* *} \mathrm{p}<0.01 ;{ }^{* * *} \mathrm{p}<0.001$ versus control.

the isolated cells and the high degree of purity of the cell cultures.

Several other markers were also investigated in this study and provided further evidence of the purity of the EVT cell population. The isolated EVT cells expressed PIGF, a key placental angiogenic factor $[15,16,18]$, which was consistent with previous studies showing upregulation of this growth factor by term extravillous trophoblast populations [33,34]. These cells were also reactive to the antibody anti-PlAP, a glycosylphosphatidylinositol-trophoblast anchored protein located on the apical membrane of the syncytiotrophoblast and in EVT cells in the term placental bed, notably in the interstitial cytotrophoblast within the maternal decidua $[18,35]$. The absence of villi cytotrophoblast and syncytiotrophoblast in our cell preparations were also suggested by the absence of desmoplakin I/II staining, peculiar to these trophoblast cell types [36].

Among all trophoblast markers, HLA-G1 is of special functional and immune importance. It is considered a tolerogenic molecule responsible for the reprogramming of local maternal immune response [37]. HLA-G1 is highly expressed by both endovascular and interstitial EVT $[38,39]$ and increases during trophoblast migration towards the spiral arteries [40] - ref-29. Consistent with the others EVT markers and similar to EVT isolated from early placentas, the isolated term basal plate EVT cells were also reactive to HLA-G1.

EVT cells isolated from term basal plate also seem to preserve their invasive phenotype through the positive expression of $\alpha 1$ and $\alpha 5$ integrins, and the negative expression of $\alpha 6$ integrin, as expressed by first trimester EVT cells [41-44]. These extracellular matrix receptors play a pivotal role in stabilizing EVT cell columns by binding to fibronectin and promoting invasiveness upon interaction with collagens and laminin [41-44].

During the first $48 \mathrm{~h}$, cultured EVT cells show a number of characteristics indicating viable and fully active cells, although without proliferative activity. Limited proliferative capacity, commonly found in fully differentiated cells, apparently does not interfere for the short periods with the biological properties of EVT cells. Prolonged EVT cell culturing, as for many other differentiated cells, results in gradually decreasing viability, suggesting low adaptability to the culture conditions or 


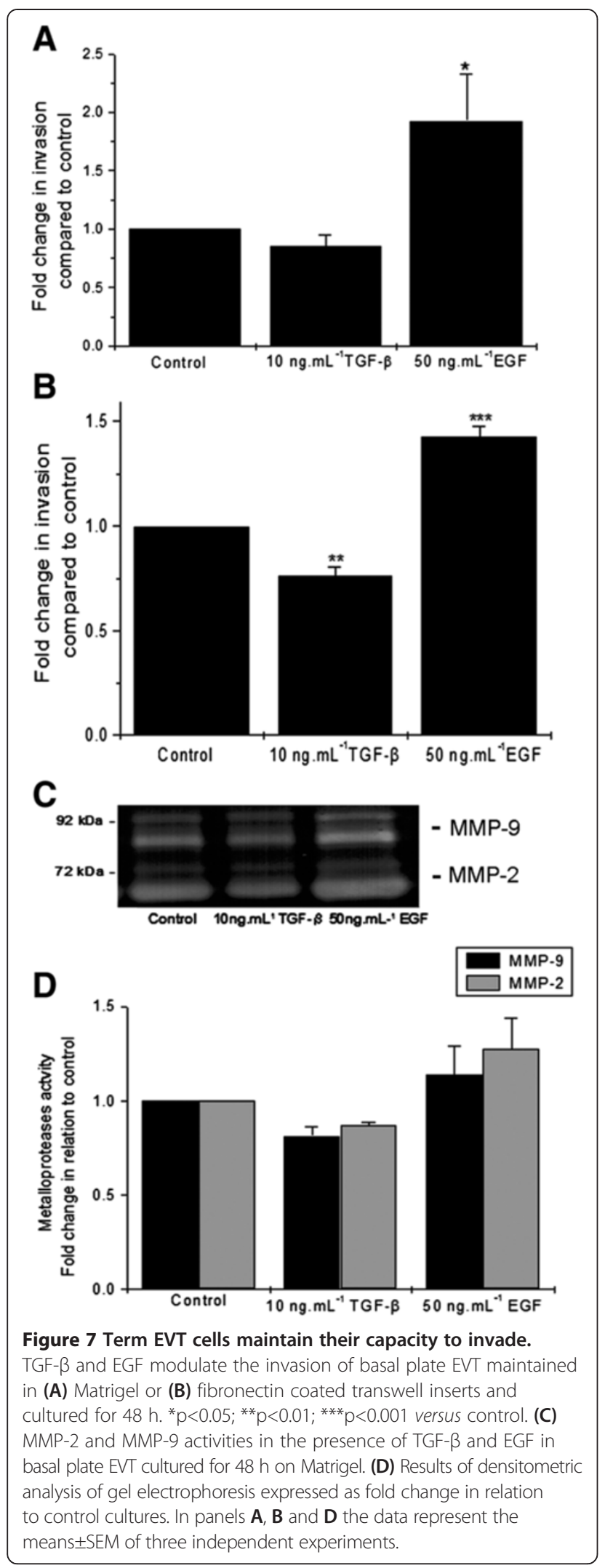

the absence of maintenance specific factors from the maternal-fetal interface [17].

Activation of MMPs is required for first trimester EVT invasion [24]. We have also shown term basal plate EVT cells express MMP-2 and MMP-9 mRNA, and active gelatinolytic secretion, showing that term EVTs have potential to invade. As in other EVT invasive models $[21,45]$, term EVT are also modulated by TGF- $\beta$ and EGF, in which EGF increases and TGF- $\beta$ decreases invasion. These data reinforce the term basal plate EVT potential for invasion. Although in situ the invasive EVT activity at term is considered down regulated/suppressed, clearly the culture conditions could change this phenotype. As expected, culture conditions did not reproduce the plethora of regulatory molecules, ECM components, hormones and other factors that constitute the placental microenvironment. These data, however, emphasize the plasticity of term EVT cells in response to different stimuli and conditions, making them suitable for experimental purposes.

Different EVT models, regardless of their sources, can provide cells of quality and specificity for a number of experimental analyses. The value of VCT cells derived from first/second trimester villi for invasion studies is irrefutable; these cells develop invasive abilities in vitro, although in vivo some of them may never interact directly with the endometrial tissue, remaining as floating villi. Term basal plate EVT, on the other hand, beside functionally active in invasion, is fully differentiated, has already invaded maternal tissues, and has been in contact with ECM, maternal immune and non-immune cells throughout gestation. In this regard, these cells are excellent candidate for studies concerning the interrelationship between maternal immune, vascular and decidual systems, and trophoblast. EVT cells isolated from term basal plate also have the advantage of not fusing to form syncytia or multinucleated cells, as seen in amniochorion EVT $[8,15]$.

Although EVT cells are abundant and easily isolated in first trimester placenta, it is not always possible to determine whether they come from a healthy gestation, as the interval between the functional unbalance and the first signs of one disease can be of several weeks. Given that, whether samples from the first trimester were committed to some further gestational pathology remains unknown.

\section{Conclusions}

An adapted method for isolating fully differentiated term basal plate EVT has been presented, which may provide a reliable in vitro model for advancing our understanding of a number of processes regulating trophoblast biology. Accordingly, term EVT cells can support future studies on the differences between first and third trimester physiology, and most importantly, comparisons with third trimester pathological gestations, even those associated 
with EVT-invasion deficiencies. Finally, this would circumvent ethical problems regarding the use of first trimester placenta in countries where abortion is not allowed.

\section{Competing interests}

Authors declare that they have no competing interests.

\section{Authors' contributions}

AUB standardized the isolation and culture of EVT cells, carried out immunofluorescence and functional assays and drafted the manuscript. SS standardized the isolation and culture of EVT cells, carried out gelatin zymography and PCR assays and drafted the manuscript. IRF helped with isolation and culture of EVT cells. KMP participated on isolation of EVT cells and immunofluorescence assays. ECC, SCS and RA participated on flow cytometry assays. MK participated in study design and donated first trimester samples and antibodies. PBB and AC participated in study design. EB conceived of the study, and participated in its design and coordination and helped to draft the manuscript. All authors have read and approved the final manuscript.

\section{Acknowledgments}

This study was supported by Fundação de Amparo à Pesquisa do Estado de São Paulo [grant no. 2009/05354-0; 2013/12243-5]; Conselho Nacional de Desenvolvimento Científico e Tecnológico [grant no. 140088/2010-5]; Coordenação de Aperfeiçoamento de Pessoal de Nível Superior [grant no. 4178-11-4] and the Austrian Science Funds [grant number P-22687-B13] We thank Rosangela Augusto de Oliveira Farias and Katarzyna Biadasiewicz for essential assistance with in vitro preparations in Brazil and Austria, respectively; to Karen Steponavicius Cruz for assistance with invasion assays and flow cytometry analysis; and to Renato Massaro and professor Silvya Stuchi Maria-Engler for support with zymography assays. We also thank professors Sergio Ferreira de Oliveira and Ruy Gastaldoni Jaeger for donating some antibodies and for the use of their laboratories.

\section{Author details}

${ }^{1}$ Department of Cell and Developmental Biology, Institute of Biomedical Sciences, University of Sao Paulo, Sao Paulo 05508-000, Brazil. ²Department of Clinical Chemistry, Faculty of Pharmaceutical Sciences, University of Sao Paulo, Sao Paulo 05508-000, Brazil. ${ }^{3}$ Department of Surgery, Veterinary Medicine and Zootechnology School, University of Sao Paulo, Sao Paulo 05508-000, Brazil. ${ }^{4}$ Department of Obstetrics and Fetal-Maternal Medicine, Reproductive Biology Unit, Medical University of Vienna, Vienna 1090, Austria. ${ }^{5}$ School of Arts, Sciences and Humanities, University of Sao Paulo, Sao Paulo 03828-000, Brazil.

Received: 9 October 2013 Accepted: 24 January 2014

Published: 28 January 2014

\section{References}

1. Gude NM, Roberts $C T$, Kalionis B, King RG: Growth and function of the normal human placenta. Thromb Res 2004, 114:397-407.

2. Genbacev OD, Prakobphol A, Foulk RA, Krtolica AR, llic D, Singer MS, Yang ZQ, Kiessling LL, Rosen SD, Fisher SJ: Trophoblast L-selectin-mediated adhesion at the maternal-fetal interface. Science 2003, 299:405-408.

3. Bischof P, Meisser A, Campana A: Biochemistry and molecular biology of trophoblast invasion. Ann NY Acad Sci 2001, 943:157-162.

4. Sibai B, Dekker G, Kupferminc M: Pre-eclampsia. Lancet 2005, 365:785-799.

5. Altieri A, Franceschi S, Ferlay J, Smith J, La Vecchia C: Epidemiology and aetiology of gestational trophoblastic diseases. Lancet Oncol 2003, 4:670-678.

6. Kemp B, Kertschanska S, Kadyrov M, Rath W, Kaufmann P, Huppertz B: Invasive depth of extravillous trophoblast correlates with cellular phenotype: a comparison of intra- and extrauterine implantation sites. Histochem Cell Biol 2002, 117(5):401-414.

7. Loregger T, Pollheimer J, Knofler M: Regulatory transcription factors controlling function and differentiation of human trophoblast a review. Placenta 2003, 24(Suppl A):S104-S110.

8. Orendi K, Kivity V, Sammar M, Grimpel Y, Gonen R, Meiri H, Lubzens E, Huppertz B: Placental and trophoblastic in vitro models to study preventive and therapeutic agents for preeclampsia. Placenta 2011, 32(Suppl):S49-S54.

9. Kliman H, Nestler J, Sermasi E, Sanger J, Strauss J: Purification, characterization, and in vitro differentiation of cytotrophoblasts from human term placentae. Endocrinology 1986, 118:1567-1582.

10. Loke YW, Burland K: Human trophoblast cells cultured in modified medium and supported by extracellular-matrix. Placenta 1988, 9:173-182.

11. Fisher SJ, Cui TY, Li Z, Hartman L, Grahl K, Zhang GY, Tarpey J, Damsky CH: Adhesive and degradative properties of human placental cytotrophoblast cells-in vitro. J Cell Biol 1989, 109(2):891-902.

12. Tarrade A, Kuen RL, Malassine A, Tricottet V, Blain P, Vidaud M, Evain-Brion D: Characterization of human villous and extravillous trophoblasts isolated from first trimester placenta. Lab Invest 2001, 81(9):1199-1211.

13. Miller R, Genbacev O, Turner M, Aplin J, Caniggia I, Huppertz B: Human placental explants in culture: approaches and assessments. Placenta 2005, 26:439-448.

14. Kliman HJ, Feinberg RF: Human trophoblast-extracellular matrix (ECM) interactions in vitro - ECM thickness modulates morphology and proteolytic activity. Proc Natl Acad Sci USA 1990, 87(8):3057-3061.

15. Ellis SA, Sargent IL, Redman CWG, McMichael AJ: Evidence for a novel hla-antigen found on human extravillous trophoblast and a choriocarcinoma cell-line. Immunology 1986, 59(4):595-601.

16. Shorter SC, Jackson MC, Sargent IL, Redman CWG, Starkey PM: Purification of human cytotrophoblast from term amniochorion by flow-cytometry. Placenta 1990, 11(6):505-513.

17. Quenby S, Mountfield S, Cartwright JE, Whitley GS, Chamley L, Vince G: Antiphospholipid antibodies prevent extravillous trophoblast differentiation. Fertil Steril 2005, 83(3):691-698.

18. Potgens AJG, Gaus G, Frank HG, Kaufmann P: Characterization of trophoblast cell isolations by a modified flow cytometry assay. Placenta 2001, 22(2-3):251-255.

19. Oki N, Matsuo H, Nakago S, Murakoshi H, Laoag-Fernandez JB, Maruo T: Effects of 3,5,3'-triiodothyronine on the invasive potential and the expression of integrins and matrix metalloproteinases in cultured early placental extravillous trophoblasts. J Clin Endocrinol Metab 2004, 89(10):5213-5221.

20. Choy MY, Manyonda IT: The phagocytic activity of human first trimester extravillous trophoblast. Human Reprod 1998, 13:2941-2949.

21. Caniggia I, Grisaru-Gravnosky S, Kuliszewsky M, Post M, Lye SJ: Inhibition of TGF-beta(3) restores the invasive capability of extravillous trophoblasts in preeclamptic pregnancies. J Clin Invest 1999, 103(12):1641-1650.

22. Caniggia I, Taylor CV, Ritchie JWK, Lye SJ, Letarte M: Endoglin regulates trophoblast differentiation along the invasive pathway in human placental villous explants. Endocrinology 1997, 138:4977-4988.

23. Wu H-X, Guo P-F, Jin L-P, Liang S-S, Li D-J: Functional regulation of thymic stromal lymphopoietin on proliferation and invasion of trophoblasts in human first-trimester pregnancy. Human Reprod 2010, 25(5):1146-1152.

24. von Rango U, Krusche CA, Kertschanska S, Alfer J, Kaufmann P, Beier HM: Apoptosis of extravillous trophoblast cells limits the trophoblast invasion in uterine but not in tubal pregnancy during first trimester. Placenta 2003, 24(10):929-940.

25. Stenqvist A, Chen T, Hedlund M, Dimova T, Nagaeva O, Kjellberg L, Innala E, Mincheva-Nilsson L: An efficient optimized method for isolation of villous trophoblast cells from human early pregnancy placenta suitable for functional and molecular studies. Am J Reprod Immunol 2008, 60:33-42.

26. Pollheimer J, Haslinger P, Fock V, Prast J, Saleh L, Biadasiewicz K, JetneEdelmann R, Haraldsen G, Haider S, Hirtenlehner-Ferber K, Knoefler M: Endostatin suppresses IGF-II-mediated signaling and invasion of human Extravillous Trophoblasts. Endocrinology 2011, 152(11):4431-4442.

27. Sinai Talaulikar V, Kronenberger K, Bax BE, Moss R, Manyonda I: Differences in collagen ultrastructure of human first trimester decidua basalis and parietalis: implications for trophoblastic invasion of the placental bed. J Obstet Gynaecol Res 2014, 40(1):80-88.

28. Borbely A, Daher S, Ishigai M, Mattar R, Sun S, Knöfler M, Bevilacqua E, Oliveira S: Decorin and biglycan immunolocalization in nonvillous structures of healthy and pathological human placentas. Histopathology 2013. doi: 10.1111/his.12304. [Epub ahead of print].

29. Chung L, Dinakarpandian D, Yoshida N, Lauer-Fields JL, Fields GB, Visse R, Nagase $\mathrm{H}$ : Collagenase unwinds triple-helical collagen prior to peptide bond hydrolysis. EMBO J 2004, 23(15):3020-3030. 
30. Manka SW, Carafoli F, Visse R, Bihan D, Raynal N, Farndale RW, Murphy G, Enghild JJ, Hohenester E, Nagase H: Structural insights into triple-helical collagen cleavage by matrix metalloproteinase 1. Proc Natl Acad Sci USA 2012, 109(31):12461-12466.

31. Frank HG, Morrish DW, Potgens A, Genbacev O, Kumpel B, Caniggia I: Cell culture models of human trophoblast: primary culture of trophoblast - a workshop report. Placenta 2001, 22(Suppl A):S107-S109.

32. Muhlhauser J, Crescimanno C, Kasper M, Zaccheo D, Castellucci M: Differentiation of human trophoblast populations involves alterations in cytokeratin patterns. J Histochem Cytochem 1995, 43:579-589.

33. Khaliq A, Li XF, Shams M, Sisi P, Acevedo CA, Whittle MJ, Weich H, Ahmed A: Localisation of placenta growth factor (PIGF) in human term placenta. Growth Factors 1996, 13(6):579-589.

34. Vuorela P, Hatva E, Lymboussaki A, Kaipainen A, Joukov V, Persico MG, Alitalo K, Halmesmaki E: Expression of vascular endothelial growth factor and placenta growth factor in human placenta. Biol Reprod 1997, 56(2):489-494

35. Leitner K, Szlauer R, Ellinger I, Ellinger A, Zimmer KP, Fuchs R: Placental alkaline phosphatase expression at the apical and basal plasma membrane in term villous trophoblasts. J Histochem Cytochem 2001, 49(9):1155-1164.

36. Beham A, Denk H, Desoye G: The distribution of intermediate filament proteins, actin and desmoplakins in human placental tissue as revealed by polyclonal and monoclonal antibodies. Placenta 1988, 9:479-492.

37. Kumpel BM, Manoussaka MS: Placental immunology and maternal alloimmune responses. Vox Sang 2012, 102(1):2-12.

38. Kovats S, Main EK, Librach C, Stubblebine M, Fisher SJ, Demars R: A class-I antigen, HLA-G, expressed in human trophoblasts. Science 1990 248(4952):220-223.

39. Le Bouteiller $P$, Blaschitz A: The functionality of HLA-G is emerging Immunol Rev 1999, 167:233-244.

40. McMaster MT, Librach CL, Zhou Y, Lim KH, Janatpour MJ, DeMars R, Kovats S, Damsky C, Fisher SJ: Human placental HLA-G expression is restricted to differentiated cytotrophoblasts. J Immunol 1995, 154(8):3771-3778.

41. Damsky CH, Librach C, Lim KH, Fitzgerald ML, McMaster MT, Janatpour M, Zhou Y, Logan SK, Fisher SJ: Integrin switching regulates normal trophoblast invasion. Development 1994, 120(12):3657-3666.

42. Aplin JD, Haigh T, Jones CJP, Church HJ, Vicovac L: Development of cytotrophoblast columns from explanted first-trimester human placental villi: Role of fibronectin and integrin alpha 5 beta 1. Biol Reprod 1999, 60(4):828-838

43. Harris LK, Jones CJP, Aplin JD: Adhesion molecules in human trophoblast a review. II. Extravillous Trophoblast. Placenta 2009, 30(4):299-230.

44. Aplin JD: Expression of integrin alpha-6-beta-4 in human trophoblast and its loss from extravillous cells. Placenta 1993, 14(2):203-215.

45. Biadasiewicz K, Sonderegger S, Haslinger P, Haider S, Saleh L, Fiala C, Pollheimer J, Knofler M: Transcription factor AP-2 alpha promotes EGF-Dependent Invasion of Human Trophoblast. Endocrinology 2011, 152:1458-1469.

doi:10.1186/1477-7827-12-7

Cite this article as: Borbely et al:: The term basal plate of the human placenta as a source of functional extravillous trophoblast cells.

Reproductive Biology and Endocrinology 2014 12:7.

\section{Submit your next manuscript to BioMed Central and take full advantage of:}

- Convenient online submission

- Thorough peer review

- No space constraints or color figure charges

- Immediate publication on acceptance

- Inclusion in PubMed, CAS, Scopus and Google Scholar

- Research which is freely available for redistribution 